\title{
MULTIDISCIPLINARY APPROACH TO MANAGING ANIMATION TEAM IN EUROPEAN BUSINESS CONTEXT
}

\author{
Dino Bruža, PhD Candidate \\ Josip Juraj Strossmayer University of Osijek, Faculty of Economics \\ Trg Ljudevita Gaja 7, Osijek, Croatia \\ dino.bruza@gmail.com
}

\author{
Andreja Rudančić, PhD, Assistant Professor \\ Libertas International University Zagreb \\ Trg John F. Kennedy 6b, Zagreb, Croatia \\ arudancic@hotmail.com
}

\section{Jerko Glavaš, PhD, Associate Professor}

Josip Juraj Strossmayer University of Osijek, Faculty of Economics

Trg Ljudevita Gaja 7, Osijek, Croatia

jerko.glavas@efos.hr

\begin{abstract}
A successful manager knows how to successfully lead a team, and the more satisfied the employees are, the more they are willing to contribute. The final result is a better company image in the market and positive economic performance indicators. Company profits when the organization continually invests in developing the business capabilities of managers to manage their teams. This paper contains managerial specific challenges, outlines the profile of an emotionally intelligent leader, and compares leadership styles in the context of EU, on the example of animation in Croatian tourism. The aim of the paper is to show how emotional intelligence influences the capabilities of animation team managers in business tasks. It will be pointed out how a manager can improve his or her emotional and communication skills. The animation manager develops emotional intelligence and communication skills by integrating technology into the business of his animation team. The descriptive method and method of compilation are used to define emotional intelligence in european practice. Questionnaire is made for analysis, to detect how significant is correlation between development of emotional intelligence and usage of information-communication technology in an animation.
\end{abstract}

Keywords: management, tourist animation, emotional intelligence, information and communication technology 


\section{INTRODUCTION}

Management is the process of designing and maintaining an environment in which individuals, working together in groups, effectively achieve their chosen goals. ${ }^{1}$ The authors Hellriegel and Slocum also gave a general definition of management, in which they stated that management represents the skill of achieving a certain effect created through other persons. ${ }^{2}$ According to the above-mentioned definition, it can be concluded that in the initial considerations, the concept of management in Europe was based on people as the main factor for achieving positive business results. Management is the process of designing, directing and harmonizing all factors of the production and service processes in which individuals, working together in a company, effectively accomplish their chosen goals in performing the functions of planning, organizing, recruiting, leading and controlling. ${ }^{3}$ Leadership, in other hand, is a narrower term than a management, which is why it is often cited as just one of the functions of management. Leadership is the process in which an individual exercises influence over a group, to achieve a common goal. ${ }^{4}$ Author Northouse gave a good direction in the scientific study of leadership and found a connection between theory and contemporary business practice in Europe. The reason why for a long time leadership was viewed as one of the functions of management is that of the statement by the authors Weihrich and Koontz, who defined management precisely through functions. The five functions of management are: planning, organizing, recruiting, leading and controlling. ${ }^{5}$ As such considerations have been stated in the last century, it is necessary to revise the fundamental principles and functions. Nowadays, definition of management points out new important elements, so previous definition of management is replaced by the new one. Management is a steering influence on market, production and/or resource operations in an organization and its units that may address both people and non-people issues and is exerted by multiple organizational actors through either anticipatory norm-setting (strategic management) or situational intervention (operational management), with the aim of achieving the unit's objectives. ${ }^{6}$ It gives a new perspective of management in the European context. In this century, the term leadership has been taken out of the context of management and is being studied separately. In the second half of the last century

Weihrich, H.; Koontz, H., Management, Zagreb, MATE, 1998, p. 4

2 Hellriegel, D.; Slocum, W.J.Jr., Management. (5), New York, Addison Wesley Publishing Company, 1988, p.6

3 Cerovic, Z., Hotel Management, Opatija, Faculty for Tourism and Hospitality Management, 2003, p. 7

4 Northouse, P.G., Leadership: Theory and Practice (6), Thousand Oaks, CA, SAGE, 2013, p. 5

5 Weihrich; Koontz, op. cit. note 2, p. 21

6 Kaehler, B.; Grundei, J., HR Governance - A Theoretical Introduction, Berlin, Springer, 2019, p. 22 
many researchers have noted the need to often use the synonym of leadership when defining the term management. Furthermore, the term manager has also long been associated with the concept of leader, although both in theory and in practice they can be separated. A manager is an expert whose first task comes from the management process, that is, executes planning processes - decision making, organizes work and business, engages and leads people, controls human, financial, physical and information resources, in order to accomplish the task. ${ }^{7}$ A leader, according to author Buble, is a manager, who identifies with the leader and usually has a practical importance that translates as a leader. ${ }^{8} \mathrm{~A}$ leader is a narrower term than manager, since the manager has a formal position in the business organization, while the leader is often outside the hierarchy. In his book, author Northouse lists the main traits of leaders: intelligent, self-confident, determined, integrity and sociability. ${ }^{9}$ However, the definition of a leadership needs to be supported by newer context. In European context it is analyzed from various perspectives, such as social, corporate, political, etc. Leadership consists of the efforts of one member of an organization with respect to other members to help them achieve their goals. ${ }^{10}$ Furthermore, there is another newer definition of leadership and leader. Leadership is about the capacity of an individual to inspire and motivates. ${ }^{11}$ For the purpose of elaborating the defined problem, paper starts with an overview of manager specific challenges in EU, and it is followed by the research methodology, findings with discussion and at the end is given the conclusion. The data used in this research were generated using the questionnaire, which is developed by authors. It was created for animation teams and managers in the area of Split (south Croatia, EU). For the research two hypotheses were put forward. H1: An emotionally intelligent manager of animation possesses a high degree of influence on the feeling of satisfaction of the employees in the animation team. The second major hypothesis H2: Information and Communication Technology influences directly and indirectly the positive development of emotional intelligence of all members of the animation team. Two auxiliary hypotheses have also been put forward to make the research of the highest quality possible. S1: The application of information and communication technology in animation management is essential for successful business communication between managers and team members. S2: Emotional intelligence development is a prerequisite for successful

\footnotetext{
$7 \quad$ Cerović, op. cit. note 2, p. 7

8 Buble, M., Management, Split, Faculty of Economics, 2000, p. 7

9 Northouse, op. cit. note 2, p. 5

10 Samah Hatem, A. et. al., Understanding of the Meaning of Leadership from the Perspective of Muslim Women Academic Leaders, Journal of Educational and Social Research vol. 6, no. 2, 2016, pp. 225-236

11 Van der Wagen, L.; White, L., Human Resource Management for the Event Industry, Oxford, Taylor \& Francis Ltd, 2014, p. 217
} 
management of the animation team. With this questionnaire can be elaborated the possibilities of enhancing emotional intelligence and communication using information and communication technology.

\section{MANAGER SPECIFIC CHALLENGES IN EUROPEAN UNION}

Animation in tourism is a European product, considering that the first animation club is open in Europe, in 1950. First animation club in Europe was Club Mediteranee, located in France. Since 1950s till today many tourist destinations developed their own animation offer, so today animation can be found in the offer of cities, hotels, resorts, clubs and camping resorts. In 2019 total number of tourist overnight stays increased, according to the European Union. Spain is leading European country, with total of 469 mil overnight stays (www.ec.europa.eu/eurostat, access date: January 31, 2020). According to the same source, France contributed to European tourism with 446 mil of overnight stays, while Germany had 436 mil overnight stays in 2019 (www.ec.europa.eu/eurostat, access date: January 31, 2020). In the whole EU foreign tourists realized 1.5 billion overnight stays, while domestic tourists realized 1.72 billion overnight stays (www.ec.europa.eu/eurostat, access date: January 31 2020). In Croatia was registered increase of 10\% of total overnight stays, comparing to the previous year 2018. The consumption of domestic tourists in EU is as twice as smaller than consumption of foreign tourists, in Croatia in 2019 was registered that foreign tourists spend six times more than domestic tourists, according to Eurostat analysis (www.ec.europa.eu/eurostat, access date: January 31 2020). Considering numbers and consumption, it is evident that there is a huge space for animation development in EU. In the same time, animation affects total tourist consumption, and that should all managers consider. Considering the fact that modern tourism makes up $10 \%$ of the total GDP in Croatia, tourist animation requires standards, and the standards should be implemented to achieve quality ${ }^{12}$

\subsection{Importance of animation managers}

An effective manager is an active leader, creating a positive work environment in which the company and its employees have the opportunity and incentive to achieve a high and required level of results. ${ }^{13}$ The animation team manager should be a proactive leader, continually creating a comfortable work environment, while encouraging his team to achieve the best results and permanently ensuring op-

\footnotetext{
12 Bruža, D.; Rudančić, A., Total Quality Management in Hotel Systems within the framework of globalization, Economic Ideas and Practice, vol. 36, no. 1, 2020, pp. 67-83

13 Buble, op. cit. note 2 , p. 8
} 
portunities for his team to be more successful. Cerović states that the manager is a professional person organizing the work. ${ }^{14}$ The animation manager uses all his / her acquired professional skills, acquired knowledge and continuously develops his / her skills to make the right decisions. An animation manager actually exists to influence a team of animators, to communicate and execute tasks as successfully as possible, in order to achieve organizational goals together. In that sense, it is important to have qualified animation manager. If the manager is successful in transferring his knowledge and experience to his team, while keeping in minds the differences between the people in the team, his team will also be more successful in achieving the required goals. Employees play the role of direct service providers. ${ }^{15}$ In order to make a profit, it is crucial to learn how to provide the best possible service. According to Bruža, Miloloža and Santo in their research, there are different levels of management in the hotel system in Europe ${ }^{16}$, and one of the levels of management is precisely animation management. The manager should be aware of his or her technical skills and then be able to work with the employees and apply the acquired knowledge, in order to fulfill everything planned. ${ }^{17}$ The emphasis on synergy is common in all special programs, and all those involved in the creation and realization of the content of the animation program. ${ }^{18}$ In order to fulfill this, it is necessary to clarify which elements are most important. The basic set of $21 \mathrm{st}$ century skills are learning skills: critical thinking, creative thinking, collaboration, communication. ${ }^{19}$ It is these skills that help the animation manager to lead his team as successfully as possible, to understand, support, nurture them, and at the same time to monitor the success of the program. The specific challenges of animation managers in terms of human resource management in European context are: recognizing a creative animator, professional selection of individuals and their potentials, organizing work and tasks, creating a vision, emotional challenges, resolving conflicts, evaluating collaboration, managing time and stress. When recognizing a creative animator, the animation manager should create an environment in the team that will suit the creativity of the animators, where they

14 Cerović, op. cit. note 3, p. 7

15 Granić, E. et. al., We are happy here and we will stay, what about you? The cross-level impact of employee loyalty and performance on student loyalty, The South East European Journal of Economics and Business, vol. 13, no. 2, 2018, pp. 7-18

16 Bruža, D.; Miloloža, I.; Santo, T., Pre-opening hotel management-phases and procedures, Interdisciplinary Management Research 15, 2019, pp. 33-50

17 Bruža, D.; Rudančić, A., Influence of information-communication trends on business communication in hotel industry", Interdisciplinary Management Research 14, 2018, pp. 3-23

18 Bruža, D.; Rudančić, A., Special city programs in the function of growth and development of tourism and hospitality offer, Interdisciplinary Management Research 13, 2017, pp. 121-138

19 Glavaš, J. et. al., 2017. Employability of university of applied sciences graduates, Interdisciplinary Management Research 13, 2017, pp. 825-840 
will realize their creative potential. The animation manager should therefore be the first to select potential animators for his team, since most human resources departments in hotel systems view economic performance through work efficiency. The biggest risk here is that one's creative potential is not recognized, simply because of the rigid technical elements and the way the human resource manager selects the most suitable employees. This may be true in other departments, but in the animation department, creativity must take precedence. Creative potential is a personality trait, which means that it reflects on different life and professional situations. ${ }^{20}$ Author Ranković points out that there are various tests in the professional selection of individuals, such as the Getcels and Jackson TAT test, the Rorschah technique, specially designed creativity tests and others. When organizing work and tasks, the animation manager must keep in mind the job characteristics. Tourist animation is a specific activity, which complements basic services. In her book, Ranković pointed out that job characteristics can be defined through skill diversity, task identity, task significance, autonomy, and evaluation point. ${ }^{21}$ When planning tasks, he must take into account the main factors of animation performance, such as space, program, and staff. In the presentation of the results of the study of the impact of emotional intelligence on the performance of the animation team in the continuation of the work, influential variables will be presented, which represent the specified specifics that the animation manager encounters on a daily basis. New constellation which this research points out: Every leader is a manager, while every manager is not necessarily a leader.

\subsection{Profile analysis of an emotionally intelligent leader}

The employee profile in each company means the totality of his / her skills, knowledge, abilities and competences that he / she can provide to the company in which he / she is employed. In order to make the most of the potential that every tourist animator can provide, the animation manager must know what kind of animator profile to employ for each and every part of the animation program. To be able to do this, as an animation manager, he must first and foremost fulfill the required profile of an emotionally intelligent tourist animation leader. As Cerović stated in his book Animation in Tourism, the general characteristics of the animator are determined by these requirements: psychophysical traits, talent and sense of contact with the guest, the required level of education and traits that will satisfy the guest. ${ }^{22}$ When analyzing the profile of an emotionally intelligent leader in tourist animation in EU,

Ranković, B., Emotional intelligent company, Beograd, Alma, 2018, p. 23

Cerović, op. cit. note 2, p. 23

Cerović, Z., Animacija u turizmu, Opatija, Faculty for Tourism and Hospitality Management, 2008, p. 67 
it is important to emphasize how the psychophysical qualities that the manager carries within himself and whether he or she is competent to do the job. In addition to their appearance and age, they include talents for specific tasks, professionalism, interest, energy, effort and will to resolve conflicts, attentiveness and confidentiality towards all team members. According to some studies to date, the most important component is communication, which will be discussed below. In this section it can be emphasized that communication skill implies that the animation manager has a distinct memory, skills in communicating with top management and members of his department as well as with guests. There is also resistance to the various pressures that are constantly imposed through tourist animation, and the ability and ease of verbal expression. The overall health of the leader is also reflected in the psychophysical and mental balance throughout the engagement. In addition, the final component in forming a leader's profile is the definition of emotional intelligence. As Salovey and Mayer have established in their works, emotional intelligence is the ability to perceive and manage their own feelings, as well as others, and to direct and act with the help of such feelings. Emotional intelligence is the ability to constantly recognize your emotions, understand them, and manage them, both in your own and in others' emotions. In the profile of an emotionally intelligent leader, several crucial factors can be observed. Ranković in her work, and before her Goleman in his, emphasize that these components are: self- awareness, empathy, self-control, intrinsic motivation and social behavior. ${ }^{23}$ Self-awareness refers to the correct perception of oneself and others in the environment. Empathy encompasses the ability to understand and perceive others' feelings. Self- control, the most important component of a leader's profile, is the ability to control one's emotions, delay the response to challenges, tolerance, and process emotions into a positive outcome. Intrinsic motivation is the desire to achieve results that positively impact the animation team. Social behavior is the ability to manage relationships with all members in the animation team, in the hotel system as a whole and in relationships with guests. The profile of the emotionally intelligent animation team leader thus formed implies the effective management of human resources in the animation team. An animation manager with the ability to communicate with a team achieves goals faster even in times of crisis, such as when the entire team needs to do more than planned, knowing that it will not necessarily be accompanied by higher revenues. As a conclusion of this section, it can be stated as follows: When creating the profile of an emotionally intelligent animation leader, the animation manager must continuously develop and simultaneously implement an operational human resources strategy that is most likely to reach productive utilization of all knowledge, skills and competencies that the animation team members possess.

23 Ranković, op. cit. note 3, p. 24 


\section{HUMAN RESOURCE MANAGEMENT IN ANIMATION IN EU}

Managing human resources in the animation team is a challenge for every animation manager in the whole EU. The very term human resources refers to the totality of human resources in an organization. It includes of knowledge, skills, abilities, creativity, motivation and work energy. All this is required to achieve organizational goals effectively. Pržulj states that this is the total intellectual, psychological, physical and social energy. ${ }^{24}$ Employees are not just one of the most important resources of a company. They are also the most expensive and problematic resources. Given the increasing importance of human resources in Europe, the management of these resources is considered a strategic interest of the organization engaged in higher levels of management. Without human efforts and their valuable skills, there is no organization and its successes. The specificities of human resource management in the animation department in EU can be reflected in the following statements: the total results of the animation department are the sum of the individual results achieved; the results of the work depend on the motivation of the animator and the animation manager; only the animation team leader can shape the vision and lead the team to that realization; the human resources in the animation department have a long-term impact on the image of the animation manager; human resources are correlated with all departmental business functions; investing in animator training and motivation is more cost effective than investing in any other department resources. Human resource planning for the organization of events is unique. Perhaps the most important specificity is that many events have "pulsating" organizational structures. This means that the organizational structure grows in terms of staff as the event approaches, but decreases rapidly when the event ends. ${ }^{25}$

\subsection{Concept of human resources management}

The leader must know the process of planning and managing human resources. Getz outlined the concept of human resource planning. According to him, this concept consists of seven main stages:

1. human resource management strategies and objectives;

2. human resource management policies and procedures;

3. recruitment, selection and introduction;

4. training and professional development;

24 Pržulj, Ž., Human Resource Management, Belgrade, Faculty of Commerce and Banking, 2007, p. 16

25 Hanlon, C. M.; Cuskelly, G., Major sport events Managing fuctuating staff Inducting event staff, Event Management, International Journal University of Queensland, Brisbane, Australia, vol. 7, no. 4, 2002, pp. 231-244 
5. monitoring and evaluation;

6. termination of business relationship, deployment and re-recruitment;

7. assessment of the planned HRM process and outcomes. ${ }^{26}$

The event's human resources strategy seeks to support its overall mission and goals. Managers of animations should make decisions about how many workers / animators are necessary for the realization of entertainment programs and events, which skills / qualifications / experience are necessary. Also, when in the process of planning the program, the quantity of entertainers/staff needs to be determined (for example, only for the exclusion of the stage events). What is most important in the overall process of leading an animation team is the correct leadership style, that is, how the animation manager fulfills all the prerequisites for being a successful animation team leader. It is well known that there are several types and styles of leadership. So far, three main leadership styles in EU have been identified and explained in all research. A successful leader has a visible impact on the team which is following him. He motivates and encourages animators to do their best at any given moment and to perceive the set vision as their own. This is achieved by the emotionally intelligent leader of the animation team. A noticeable lack of emotional intelligence is identified when the animation manager relies entirely on the hierarchy and the power he or she has in that position. In this case, the final results are lacking, the vision is unfulfilled, and this can be reflected in the economic performance indicators of the animation department. Daniel Goleman states that there are 6 leadership styles: command style, authoritative / visionary style, coaching style, affiliate / associate style, democratic style and progressive / striking style. ${ }^{27}$ In order to link the leadership style to emotional intelligence and indicate a correlation, each of the styles will be briefly explained. The command style is often negative, but useful in crisis situations and thus gives the leader specific direction in high-risk situations. The visionary style encourages the members of the animation team towards the realization of the vision, creates a mostly positive atmosphere, and is useful in situations where clear direction, concrete tasks and accurate execution are required. The coaching style is used to help team members contribute more to their team, connect animators with managerial goals and is highly positive. Affiliate / collaborative style creates a harmonious atmosphere, allows all members of the animation team to connect with each other, and is ideal at the beginning of the work and during a stressful period. The intensity is positive and strengthens the interconnectedness. The democratic style of an animation leader is of positive

\footnotetext{
26 Getz, D., Event Management and Event Tourism, New York, Cognizant Communication Corp., 1997, p. 22

27 Goleman, D., Leading Resonant Teams, Leader to Leader 25, 2002, pp. 24-30
} 
intensity, appreciates the contribution of each member, respects their diversity and encourages the animation team members to become more involved with the team and the vision of the leader. The progressive style of the leader is characteristic when the team is composed of competitive members, so the leader thus produces high quality results. There is high motivation within the whole team, but often a negative influence on the animation team due to the expressed ambition of the team members. In this case, the leader sets high goals, exciting tasks and programs that are challenging for animators. An emotionally intelligent animation team leader anticipates future stressful situations, approaches each member individually, adjusts the animation program plan, and motivates the members as the animator's motivation decreases. When an animation manager does not achieve the positive effects of acting on their team, then it is classified as emotionally unstable or unintelligent, or deviates from the team leader profile. The hardest part is identifying potential conflicts and resolving them. The following section describes in more detail how to enhance the emotional intelligence and communication skills of leaders using information and communication technology.

\subsection{The correlation analysis of emotional intelligence and communication skills in the use of information and communication technology in EU}

In order to achieve successful communication, certain prerequisites must be met. These assumptions are correlated with information and communication technology and emotional intelligence of the animation team leader. When the animation manager is emotionally stable and uses the full potential of the use of information and communication technology in his work, then stability and assurance are achieved that each member of the animation team will fully complete the planned tasks and achieve a vision together. The stability and security of the individual in every respect should be an imperative goal. ${ }^{28}$ Employee performance is a multidimensional structure, as Granić, Babić-Hodović and Arslanagić-Kalajdžić cite in their research, in which they mention that this structure has different explanations, depending on the source cited. ${ }^{29}$ In this case, the manager takes all the planned activities that are in the strategy of the animation department of a particular system. In the case of emotional intelligence development in the case of EU, various techniques are used during managerial training and personal development. An animation manager can be a successful leader if he or she knows how to manage themselves and others in communication processes, using information and communication technology tools. Through communication, the views and feelings of the interlocutor are expressed

\footnotetext{
28 Vojinović, Ž.; Leković, B.; Glavaš, J., Risk Management of the socio-economic system and insurance as a stability instrument, Interdisciplinary Management Research vol. 15, 2019, pp. 203-218

29 Granić et.al., op. cit. note 2, p. 7
} 
and the outcome can be positive and negative. As Galičić and Šimunić state in their research, for the rational application and development of information technology in hotel companies, several prerequisites need to be met: to recognize the need to apply information technology; to plan the construction and development of the business system as a whole; standardize equipment, documentation and methods of using information technology; to organize the process of managing and managing the conditions of application of information technology. ${ }^{30}$ Given that animation is one of the departments of the hotel system across whole EU, the above can be applied within the research of the problems of this paper. Information management has certain specificities, and they are conditioned by a number of elements. In the animation team, business communication is subject to information and communication trends, i.e. ICT greatly affects the quality of communication between team members and the animation manager. Using technology, the animation manager has control over the team, shortening the time in the process of transmitting information and tasks, thereby influencing the control of stress factors. By reducing stress, it enhances emotional intelligence, that is, leads to controlled conditions. The most important information and communication tools for successful communication are: direct communication using mobile devices, via text messaging and video calls, the use of group calling applications, emails and social networks. In one study on the impact of information and communication technology and tools on business communication, significant results were obtained. In that study, Bruža and Rudančić stated the degree of frequency of use of certain attributes in business communication. There is a noticeable progress in the use of modern technological solutions for the transfer of information. The way and means of business communication ICT are most influential on official email and social networks. 57\% of the respondents in this survey stated that information and communication trends have the greatest influence on the use of official email as a means of business communication, which is confirmed by the percentage of choosing this answer. ${ }^{31}$ With greater use of information and communication tools to improve communication among members of the animation team, the degree of controlled conditions is increasing. This makes the animation manager more able to respond properly to all situations. The use of information technology intensifies communication, reduces costs and supplies, enhances procurement and marketing through information and communication infrastructure, enables real-time information for managers, and encourages

30 Galičić, V.; Šimunić, M., Information Systems and Electronic Business in Tourism and Hospitality, Faculty of Tourism and Hospitality Management in Opatija, 2006, p. 98

31 Bruža, D.; Rudančić, A., Influence of information-communication trends on business communication in hotel industry", Interdisciplinary Management Research, vol. 14, 2018, pp. 3-23 
the development of new businesses. ${ }^{32}$ To conclude this consideration, it can be stated that for the information system in hotels as well as in the animation department, the property management system (PMS) is one of the most important information and communication applications for the manager. ${ }^{33}$

\section{ANALYSIS OF RESEARCH RESULTS}

The assumption is that the animation manager is not necessarily a leader, because as already stated, every leader is a manager, while every manager is not necessarily a leader. The authors set out the main and supporting hypotheses as the starting point. The subject of the research is the influence of emotional intelligence on the management of the animation team, regarding the tourist business in Croatia. The goal of the research is to show how emotional intelligence influences the ability of the animation team manager to successfully manage the animation team. The purpose of the research is to present the level of influence of information and communication technology on the development of emotional intelligence and communication skills. Animation teams were observed in two cases of animation teams in one camp in Stobreč near Split and in one tourist club in Dubrovnik. These two animation departments are representative for a number of reasons. The main reasons are the number of members of both teams, complete coverage of animation activities for all guest groups, the number of visits to the animation programs, the long history of business in both departments within their hotel and camping systems. Following these, two main hypotheses were put forward. H1: An emotionally intelligent animation manager has a high degree of influence on the animation team's sense of satisfaction. H2: Information and communication technology influence directly and indirectly the positive development of emotional intelligence of all members of the animation team. Through the first main hypothesis, the research examined how business psychology connects with business economics, that is, whether there is any and the degree to which it is correlated with the emotional intelligence and animation management. During the research, there was a need to establish auxiliary hypotheses, which could confirm or refute the main hypotheses. S1: The application of information and communication technology in animation management is essential for successful business communication between managers and team members. S2: Development of emotional intelligence is a prerequisite for successful management of the animation team. In the first part of the research, the EFQM Excellence model was used. It can be

32 Stipanović, C., Concept and development strategy in tourism, Opatija, Faculty for Tourism and Hospitality Management in Opatija, 2006, p. 205

33 Kokaz, K.; Murphy, H., An Investigation of dana management and Property Management systems in hotels, Tourism and Hospitality Management, An International Journal of Multidisciplinary Research for South-Eastern Europe, vol. 17, no. 1, 2011, pp. 101-115 
divided into three research phases: leadership strategy, processes and results. ${ }^{34}$ This model ensured that all necessary variables were included to investigate the impact of information and communication technology and tools on the communication of animation managers and members and the quality of those relationships.

Figure 1. EFQM Excellence model in EU

\begin{tabular}{|l|l|l|}
\hline Factors & Results & Learning and Inovation \\
\hline Leadership (10\%), HR (9\%), & Employee Satisfaction (9\%), & Complete: 100\% \\
Strategy (8\%), Resources & Consumer Satisfaction & \\
$(9 \%)$, Process (14\%) & $(20 \%)$, Social Impact (6\%), & Going back at beginning \\
\hline & Business Results (15\%) & \\
\hline
\end{tabular}

Source: authors, following The European Foundation for Quality Management, [https://www. efqm.org/index.php/efqm-model/] Last accessed 15 January 2020

An important segment of the model is the combination of animation leadership, using a variety of information and communication channels, to successfully complete the process, manage human resources, to maximize business results. In this case, the results have a significant impact on reducing the stress and stressors of communication, the ability to control the situation and increase the satisfaction of members. This is achieved if the manager possesses emotional intelligence to some extent. The observed research variables are: direct communication using mobile devices, via text messaging and video calls, the use of group calling applications, emails and social networks.

Table 1. Frequency of Usage of Communication Attributes

\begin{tabular}{|l|c|c|c|}
\hline Atribute & $\begin{array}{c}\text { Frequently } \\
\text { used (\%) }\end{array}$ & $\begin{array}{c}\text { Preferred } \\
\text { to use (\%) }\end{array}$ & $\begin{array}{c}\text { Necessary for } \\
\text { business com- } \\
\text { munication (\%) }\end{array}$ \\
\hline Private email & 68 & 70 & 68 \\
\hline Official email (shared email used by team) & 70 & 65 & 60 \\
\hline Text and voice messages via cell phone & 24 & 26 & 30 \\
\hline Social network (chat, video calling, combined) & 45 & 42 & 44 \\
\hline Call via cell phone & 85 & 75 & 80 \\
\hline Directly face to face (live or via video link) & 78 & 70 & 68 \\
\hline Written messages on papers & 10 & 8 & 5 \\
\hline $\begin{array}{l}\text { Mixed (depending on the time, place, mode, } \\
\text { type and content of business communication) }\end{array}$ & 55 & 45 & 40 \\
\hline
\end{tabular}

Source: authors research

34 Cetinski, V. , Strateško upravljanje razvojem turizma i organizacijska dinamika, Opatija, Fakultet za turistički i hotelski menadžment, 2005, p. 23 
Given that multiple choices were made, the animation department respondents overwhelmingly chose to use smart cellular telephones, whether audio or video, with results ranging between $75 \%$ and $85 \%$. To a minimum, the classic method of communication, handwriting and conveying a written message is used, to which a small percentage of respondents, between 5 and $10 \%$, responded. In addition to audio and video communication, the respondents indicated that it was very important to them to communicate via electronic mail, in which case between 60 and $70 \%$ of respondents stated that they use this type of communication - most often when sending materials, documents and programs for animation activities such as activity schedules, weekly work and assignment plans, and receiving feedback from surveys that guests complete. The third segment that facilitates their communication is the use of social networks and applications, through which they can again combine text messages and audio-visual calls. Almost 50\% of respondents expressed a positive attitude towards this information and communication tool for successful communication. Consequently, the auxiliary hypothesis $S 1$ could be positively confirmed. In order to validate or deny $S 2$, it was necessary to carry out additional research in another set of questions, to evaluate the criteria related to the role and impact of emotional intelligence. The following are selected variables that are indicators of the existence or absence of emotional intelligence: compassion, listening, understanding, friendship, mutual support, conflict, stress, expression, and motivation by the leader. The questions were intended to measure certain elements of significance, which would contribute to the evaluation of their contribution to the overall assessment of the impact of emotional intelligence, and ultimately to the confirmation or refutation of $\mathrm{H} 1, \mathrm{H} 2$ and $\mathrm{S} 2$. By statistically processing the obtained data, the results indicated that $\mathrm{H} 1$ and $\mathrm{H} 2$ were fully accepted and positively confirmed, while $S 2$ was partially accepted. The results according to the test elements are shown below. First, a tabulation of the numerical results will be presented, followed by a descriptive analysis and conclusions.

Table 2. Age structure of respondents

\begin{tabular}{|l|c|c|}
\hline Age group & Frequency of appearance & Relative frequency \\
\hline $\mathbf{1 8}-\mathbf{2 5}$ & 26 & 0,52 \\
\hline $\mathbf{2 6 - 3 0}$ & 18 & 0,36 \\
\hline $\mathbf{3 1 - 3 5}$ & 5 & 0,10 \\
\hline $\mathbf{3 6}$ and more & 1 & 0,02 \\
\hline
\end{tabular}

Source: authors research

The total number of respondents was 50 and all respondents answered the age question. Out of the total, the majority of respondents were in the 18-25 age 
group, or $52 \%$. There are at least 36 of them in the group and there is only one respondent in this group, which represents $2 \%$ of the total.

Table 3. Respondents by gender

\begin{tabular}{|l|c|c|}
\hline Gender & Frequency of appearance & Relative frequency \\
\hline Male & 22 & 0,44 \\
\hline Female & 28 & 0,56 \\
\hline
\end{tabular}

Source: authors research

The study was attended by 28 female persons and 22 male persons, i.e. the total female respondents was 56\%, 12 percentage points higher than the number of male respondents, totaling 22 . The following two tables show the statistical results of testing the elements of emotional intelligence the performance of the department and the frequency of susceptibility of the elements of emotional intelligence are influenced by information and communication technology.

Table 4. E.I. Elements evaluation on team performance

\begin{tabular}{|l|c|c|}
\hline Statistical Indicators & Correlation with usage of ICT & Influence of Manager \\
\hline Sample & 50 & 50 \\
\hline Sum of grades $\boldsymbol{\Sigma}$ & 195 & 215 \\
\hline Average rating X & 3,50 & 4,0 \\
\hline Median M & 3 & 4 \\
\hline The standard deviation $\boldsymbol{\delta}$ & 0,94 & 1,05 \\
\hline The variance $\boldsymbol{\sigma}$ &, 890 & 1,580 \\
\hline
\end{tabular}

Source: authors research

Table 5. Frequency of E.I. Elements Susceptibility to ICT Influence

\begin{tabular}{|c|c|c|c|c|c|c|}
\hline & ELEMENT & \multicolumn{5}{|c|}{ GRADES } \\
\hline & $N=50$ & 1 & 2 & 3 & 4 & 5 \\
\hline \multirow{3}{*}{1.} & Compassion & 20 & 25 & 5 & 0 & 0 \\
\hline & $\%$ & 40 & 50 & 10 & 0 & 0 \\
\hline & Average & \multicolumn{5}{|c|}{1,7} \\
\hline \multirow{3}{*}{2.} & Listening & 0 & 0 & 12 & 18 & 20 \\
\hline & $\%$ & 0 & 0 & 24 & 36 & 40 \\
\hline & Average & \multicolumn{5}{|c|}{4,16} \\
\hline \multirow{3}{*}{3.} & Understanding & 0 & 4 & 15 & 16 & 15 \\
\hline & $\%$ & 0 & 8 & 30 & 32 & 30 \\
\hline & Average & \multicolumn{5}{|c|}{3,84} \\
\hline
\end{tabular}




\begin{tabular}{|c|c|c|c|c|c|c|}
\hline \multirow{3}{*}{4.} & Friendship & 1 & 4 & 5 & 20 & 20 \\
\hline & $\%$ & 2 & 8 & 10 & 40 & 40 \\
\hline & Average & \multicolumn{5}{|c|}{4,1} \\
\hline \multirow{3}{*}{5.} & Mutual support & 6 & 9 & 18 & 7 & 10 \\
\hline & $\%$ & 12 & 18 & 36 & 14 & 20 \\
\hline & Average & \multicolumn{5}{|c|}{3,12} \\
\hline \multirow{3}{*}{6.} & Conflict & 0 & 3 & 12 & 25 & 10 \\
\hline & $\%$ & 0 & 6 & 24 & 50 & 20 \\
\hline & Average & \multicolumn{5}{|c|}{3,84} \\
\hline \multirow{3}{*}{7.} & Stress & 0 & 1 & 7 & 17 & 25 \\
\hline & $\%$ & 0 & 2 & 14 & 34 & 50 \\
\hline & Average & \multicolumn{5}{|c|}{4,32} \\
\hline \multirow[t]{4}{*}{8.} & $\begin{array}{l}\text { Motivation by } \\
\text { leader }\end{array}$ & 0 & 0 & 6 & 14 & 30 \\
\hline & $\%$ & 0 & 0 & 12 & 28 & 60 \\
\hline & Average & \multicolumn{5}{|c|}{4,48} \\
\hline & $\begin{array}{l}\text { Overall average } \\
\text { rating }\end{array}$ & \multicolumn{5}{|c|}{3,70} \\
\hline
\end{tabular}

Source: authors research

It is important to point out that the participants in the survey could have assigned one of a total of five ratings, where a rating of one indicated the absence of influence of information and communication technology, and a rating of five indicated the full impact of that technology on the given elements, which were proposed as influencing factors, to the development of emotional intelligence. According to the results presented, the following conclusions can be drawn. Given the total number of respondents (50), the lowest average rating for the variable is compassion, with an average of 1.8, as an element subject to the lowest frequency of influence, using information and communication technology in business communication. In contrast, the highest impact of technology in business communication is on the motivation variable by the animation manager, with an average score of 4.48. In an in-depth interview with the heads of the animation department, such results are confirmed by their claims that by using various tools and applications during the performance of tasks, as well as during and before business processes, the tools have had the greatest impact on their employees, motivating them, while having contact with them throughout the duration of the job. Employees value it highly when they are in constant contact with the animation manager, and by using information tools and applications, they can more easily communicate and receive instant feedback on all tasks and goals of the program being performed. The next variable most influential when using this technology is the element of 
stress, with an average of 4.32. This is a significant indicator that the degree of use of technology in business communication influences the level of stress.

The more demanding the tasks or situations, the greater the stress, but it is possible to control the stress and to a certain degree minimize it. It is very important for both the animation manager and the animators to be in touch, with technology enabling them to contact their manager at any time, reducing their stress on certain situations. Nevertheless, summing up all the results obtained, we reach an average score of 3.7. The main hypotheses $\mathrm{H} 1$ and $\mathrm{H} 2$ thus established can be positively accepted and confirmed. An emotionally intelligent animation manager has a noticeable effect on the employees' sense of satisfaction in his animation team. The more the team uses modern applications and smart devices for the purpose of constant communication and informing its employees, the more positively the employees will respond, perform tasks, have a sense of belonging and thus be more satisfied with their work. However, the development of emotional intelligence is not a prerequisite for successful management of the animation team. This opens the possibility for further research in this direction, analyzing what would be the preconditions for successful management of an animation team and whether the same preconditions are equally important for each animation team. According to this research, as a sample of two different animation teams operating in different environments and in business organizations, it could be recognized that the elements that affect emotional intelligence are alike. Likewise, the degree of use of information and communication technology was the same in both animation teams and there were no significant discrepancies that would make the continuation of the research potentially questionable.

\section{CONCLUSION}

Emotional intelligence has become an integral part of the contemporary manager's psychophysical profile. Emotional intelligence is the ability to constantly recognize emotions, understand them, and manage them, both in own and in others' emotions. Several crucial factors can be observed in the profile of an emotionally intelligent leader. The assumption is that the Croatian animation manager is not necessarily a leader, because as already stated, every leader is a manager, while every manager is not necessarily a leader. When the animation manager is emotionally stable and uses the full potential of the use of information and communication technology in his work, then stability and assurance are achieved so that each member of the animation team can fully complete the planned tasks and achieve a vision together. According to the results obtained, two main hypotheses were accepted and confirmed. With the auxiliary hypotheses, one auxiliary 
was accepted, while the other was partially accepted. It was stated that emotional intelligence influences to some extent the success of leading an animation team, while the use of information and communication technology in communicating has a significant influence on the level of emotional intelligence in the direction of animation management. Emotional intelligence itself is not a prerequisite for a successful animation team in Croatia, but it certainly contributes to more positive results when it comes to the level of satisfaction and belonging of employees to a particular animation team. In the context of the research, an important segment of the model is the combination of animation leadership, using a variety of information and communication channels, to successfully complete the process, manage human resources, to maximize business results. In this case, the results have a significant impact on reducing the stress and stressors of communication, the ability to control the situation and increase the satisfaction of members, which is achieved if the manager possesses emotional intelligence to some extent. The observed research variables were: direct communication using mobile devices, via text messaging and video calls, use of group calling applications, emails and social networks. The main conclusion of the research that emerged from data analysis and theoretical framework analysis is that the animation manager in Croatia simultaneously develops emotional intelligence and communication skills, integrating technology into the business of his animation team.

\section{REFERENCES}

\section{BOOKS AND ARTICLES}

1. Bruža, D.; Rudančić, A., Special city programs in the function of growth and development of tourism and hospitality offer, Interdisciplinary Management Research, vol. 13, 2017, pp. 121-138

2. Bruža, D.; Rudančić, A., Influence of information-communication trends on business communication in hotel industry, Interdisciplinary Management Research, vol. 14, 2018, pp. 3-23

3. Bruža, D.; Miloloža, I.; Santo, T., Pre-opening hotel management-phases and procedures, Interdisciplinary Management Research, vol. 15, 2019, pp. 33-50

4. Bruža, D.; Rudančić, A., Total quality management in hotel systems within the framework of globalization, Economic Ideas and Practice, vol. 36, no. 2, 2020, pp. 67-83

5. Buble, M., Management, Split, Faculty of Economics, 2000

6. Cerović, Z., Hotel Management, Opatija, Faculty for Tourism and Hospitality Management in Opatija, 2003

7. Cerović, Z. Animation in tourism, Opatija, Faculty for Tourism and Hospitality Management in Opatija, 2008

8. Cetinski, V., Strategic management of tourism development and organizational dynamics, Opatija, Faculty for Tourism and Hospitality Management in Opatija, 2005 
9. Galičić, V.; Šimunić, M., Information Systems and Electronic Business in Tourism and Hospitality, Opatija, Faculty for Tourism and Hospitality Management in Opatija, 2006

10. Ganić, E.; Babić-Hodović, V.; Arslanagić-Kalajdžić, M., We are happy here and we will stay, what about you? The cross-level impact of employee loyalty and performance on student loyalty, The South East European Journal of Economics and Business, vol. 13, no. 2, 2018, pp. 7-18

11. Getz, D., Event Management and Event Tourism, New York, Cognizant Communication Corp, 1997

12. Glavaš, J.; Stanić, M.; Stanić Šulentić, M., Employability of university of applied sciences graduates, Interdisciplinary Management Research 13, 2017, pp. 825-840

13. Goleman, D., Emotional intelligence in business, Zagreb, Mozaik, 1998

14. Goleman, D., Leading Resonant Teams, Leader to Leader 25, 2002, pp. 24-30

15. Hanlon, Clare M.; Cuskelly, G., Major sport events Managing fluctuating staff Inducting event staff, Event Management, International Journal University of Queensland, Brisbane, Australia, vol. 7 , no. 4, 2002, pp. 231-244

16. Hellriegel, D.; Slocum, W.J.Jr., Management, 5th Edition, New York, Addison Wesley Publishing Company, 1988

17. Kaehler, B.; Grundei, J., HR Governance - A Theoretical Introduction, Berlin, Springer, 2019.

18. Kokaz, K.; Murphy, H., An Investigation of dana management and Property Management systems in hotels, Tourism and Hospitality Management, An International Journal of Multidisciplinary Research for South-Eastern Europe, vol. 17, no. 1, 2011, pp. 101-115

19. Northouse, P.G., Leadership: Theory and Practice. 6th Edition, Thousand Oaks, CA, SAGE, 2013

20. Pržulj, Ž., Human Resource Management, Belgrade, Faculty of Commerce and Banking, 2007

21. Ranković, B., Emotional intelligent company. Beograd, Alma, 2018

22. Samah Hatem, A.; Abu Daud, S.; Khairuddin, I., Understanding of the Meaning of Leadership from the Perspective of Muslim Women Academic Leaders, Rome, Journal of Educational and Social Research, vol. 6, no. 2, 2016, pp. 225-236

23. Stipanović, C., Concept and development strategy in tourism, Opatija, Faculty for Tourism and Hospitality Management in Opatija, 2006

24. Van der Wagen, L.; White, L., Human Resource Management for the Event Industry, Oxford, Taylor \& Francis Ltd, 2014

\section{WEBSITE REFERENCES}

1. European Union, [www.ec.europa.eu/eurostat] Last accessed 31 January 2020

2. The European Foundation for Quality Management, [https://www.efqm.org/index.php/ efqm-model/] Last accessed 15 January 2020 